V. V. Boyko ${ }^{1,2}$,

I. V. Krivorotko 1,2 ,

V. A. Lazirskiy ${ }^{2}$

${ }^{1}$ State Institution «Zaitsev V. T. Institute of General and Urgent Surgery of National Academy of Medical Sciences of Ukraine» Kharkiv, Ukraine

${ }^{2}$ Kharkiv National Medical University

\section{TREATMENT OF PATIENTS WITH GASTRIC CANCER COMPLICATED BY PERFORATION}

Abstract. Introduction. Despite the declining incidence of gastric cancer, the problem of treatment of complicated forms of the disease remains one of the most complex and relevant. The aim of the study was to improve the results of treatment of patients with complicated gastric cancer.

Materials and methods. The study is based on the analysis of the results of treatment of 19 patients with gastric cancer complicated by perforation, who were treated at the "State Institution «Zaitsev V.T. Institute of General and Urgent Surgery of National Academy of Medical Sciences of Ukraine" from 2011 to 2020 aged 18 to 85 . All patients were divided into two groups: comparison - $9(47.3 \%)$ patients (were treated from 2011 to 2015), the main - $10(52.7 \%)$ patients (treatment period from 2016 to 2020).

Results and discussion. In the comparison group, conventional surgical tactics and operations were used. The main group used activeindividualized two-stage surgical tactics, which involve suturing a perforation hole in the first stage and combined and reconstructive surgery in the second. Radical operations were performed in 10 $(52.6 \%)$ patients; in $9(47.4 \%)$ - palliative and symptomatic. Postoperative complications occurred in 5 patients (26.3\%), postoperative mortality was $26.3 \%$ (5 patients).

Conclusions. In patients with gastric cancer complicated by perforation, in a serious condition of the patient and the presence of diffuse peritonitis, we consider it appropriate to use two-stage surgical tactics. The introduction of the proposed surgical tactics and new surgical interventions helped to increase the number of radical operations from $4(21.0 \%)$ in the comparison group to $6(31.6 \%)$ in the main group and reduce postoperative mortality from $15.8 \%$ to $10.5 \%$, respectively.

Key words: gastric cancer, perforation, surgical treatment.

\section{Introduction}

Despite the declining trend in the incidence of gastric cancer, the problem of treatment of complicated forms of the disease remains one of the most complex and relevant $[1,2,3]$. Gastric cancer occupies one of the leading positions in the structure of malignant neoplasms, accounting for $8.6 \%$ of all tumors detected in the world. In Ukraine, the incidence rate in 2017 was 23.9 per 100 thousand adult population (30.9 among men and 17.9 among women), among the causes of death of cancer patients, gastric cancer ranks third in men $(9.0 \%)$ and sixth place $(5.6 \%)$ in women. Up to $60-80 \%$ of patients are admitted for treatment with neglected forms of the disease in the presence of severe complications $[2,4]$. In recent years, the literature provides conflicting data on the incidence of perforation in gastric cancer $(0.39 \%$ to $9.6 \%)$ and mortality $(11.4 \%$ to $46.0 \%)[2,4,5,6]$.

\section{The purpose of the study}

To improve the results of treatment of patients with complicated gastric cancer.

\section{Materials and methods}

The study is based on the analysis of the results of treatment of 19 patients with gastric cancer complicated by perforation, who were treated at the «Institute of General and Emergency Surgery. V. T. Zaitseva National Academy of Medical Sciences of Ukraine» from 2011 to 2020 aged 18 to 85. This was $4.5 \%$ of all patients with complicated gastric cancer during this period. There were 13 men $(68.4 \%)$ and 6 women $(31.6 \%)$. All patients were randomized into two groups: comparison $9(47.3 \%)$ patients (were treated from 2011 to 2015), the main - $10(52.7 \%)$ patients (treatment period from 2016 to 2020).

In 15 patients $(78.9 \%)$ perforation was an isolated complication, in the remaining $4(21.1 \%)$ - there was a combination of perforation with acute gastric bleeding. There were no significant differences between the groups in age, sex of patients, comorbidity and stage of gastric cancer. Commonly used surgical tactics and operations were used in the comparison group. The main group used two-stage surgical 
tactics and developed combined and reconstructive operations.

Lesions of the cardiac part of the stomach were noted in $3(15.8 \%)$ patients, the body of the stomach - in $6(31.6 \%)$, the antral part of the stomach - in $9(43.3 \%)$, subtotal lesions of the stomach - in $1(5.3 \%)$ patient.

Of the 4 patients who had acute gastric bleeding, mild blood loss, according to the classification of O. O. Shalimov and V. F. Saenko (1987) [4], set at $2(10.5 \%)$; moderate - in $2(10.5 \%)$ patients.

Morphologically, gastric tumors were represented by adenocarcinomas of varying degrees of differentiation: G1 - in 5 (26,3\%), G2 - in $5(26,3 \%)$, $\mathrm{G} 3$ - in $7(36,9 \%), \mathrm{G} 4-$ in $2(10,5 \%)$ of patients.

In the studied groups, according to CT, there was a spreading of gastric tumors in neighboring organs: colon and mesentery - in $11(57,9 \%)$, pancreas in $4(21,1 \%)$, liver - in $2(10,5 \%)$, and invasion of several organs - in $2(10,5 \%)$ patients.

The distribution of patients by stages of TNM is presented in table 1 .

Distribution of patients with gastric cancer according to the TNM classification

\begin{tabular}{|c|c|c|}
\hline Indicator & Comparison group $(\mathbf{n}=\mathbf{9})$ & Main group $(\mathbf{n}=\mathbf{1 0})$ \\
\hline T4N0M0 & $2(10,5 \%)$ & $3(15,8 \%)$ \\
\hline T4N1M0 & $5(26,3 \%)$ & $4(21,1 \%)$ \\
\hline T4N2M0 & $2(10,5 \%)$ & $3(15,8 \%)$ \\
\hline
\end{tabular}

\section{Results and discussion}

Perforation of gastric cancer occurs in $0.39-9.6 \%$ of complications of gastric cancer, and the development of this complication is often the first manifestation of the disease [2, 3]. Naturally, it is impossible to establish the prevalence of cancer, stage of the disease, lymph node involvement and germination in adjacent organs before the operation.

To exclude covert and atypical perforation of the tumor, we use the following, extremely important in practical terms, the algorithm: 1) an overview of the abdominal cavity; 2) Henelt's test (pneumogastrography); 3) endoscopic examination of the stomach with air insufflation directly into the crater of a cancerous ulcer, followed by a review radiography of the abdominal cavity; 4) laparoscopic examination; 5) laparotomy. Adherence to this examination protocol allows you to establish the correct diagnosis and perform timely surgery.

At perforation of tumors of a stomach the usual operation is primary resection of a stomach (a gastrectomy). Contraindications to it were considered severe general condition of the patient, old age and senile age, general peritonitis, germination in neighboring organs. In recent years, there have been many works on two-stage surgical tactics with delayed gastrectomy or resection of the stomach in the second stage, including laparoscopic.
At the general severe condition of the patient (diffuse peritonitis, immobile tumor), we performed suturing of the perforation with drainage of the abdominal cavity. Suturing perforation of gastric cancer has significant difficulties. The edges of the perforation are usually infiltrated, rigid, brittle, bleeding. Suturing such tissues, especially in the case of a disintegrating tumor, is not effective - the sutures are cut, which does not provide a reliable seal of perforation. In such cases, the plastic of the puncture hole was performed with a cap on the leg according to Oppel-Polikarpov's method. Some authors believe that after suturing a perforated cancer, the subsequent radical operation becomes in most cases impossible due to the progression of the process. In some cases, when it is impossible to perform perforation suturing, the defect of the stomach wall is used as a fistula - a Foley catheter is inserted into the perforation hole.

Two-stage surgical interventions were performed in 9 patients (main group - 6) with perforation of gastric tumor. In 4 cases at performance of delayed operations it was possible to carry out a radical combined gastrectomy, at 2 patients - palliative resections of a stomach. In 2 cases after suturing of perforation of a tumor there were profuse bleedings, at 1 patient there was a failure of seams with lethal consequence. The remaining 10 patients underwent primary gastrectomy (comparison group -6 patients, 4 of them - palliative). 2 patients died due to peritonitis. The data are presented in table 2 .

Distribution of patients with gastric cancer by the nature of operations

\begin{tabular}{|l|c|c|}
\hline & $\begin{array}{c}\text { Comparison group } \\
(\mathrm{n}=9)\end{array}$ & $\begin{array}{c}\text { Main group } \\
(\mathrm{n}=10)\end{array}$ \\
\hline Radical operations & $4(21,0 \%)$ & $6(31,6 \%)$ \\
\hline Palliative operations & $5(26,3 \%)$ & $4(21,0 \%)$ \\
\hline Primary gastrectomy & $6(31,6 \%)$ & $4(21,0 \%)$ \\
\hline Two-stage resection & $3(15,8 \%)$ & $6(31,6 \%)$ \\
\hline
\end{tabular}

At present, there is no standard surgical method due to the variety of severity and location of the disease, so an individual approach to the choice of surgical method is used. The main radical operations are distal gastrectomy, total gastrectomy, proximal gastrectomy. Distal gastrectomy was performed in exophytic tumors of the antrum of the stomach that do not extend above the angle of the stomach.

At a gastrectomy we prefer esophagojejunoanastomoses in our modification and modification of $\mathrm{Ru}$ (at reconstructive operations). Since 1989, the clinic, along with the well-known, used its own method of esophagojejunoanastomosis. The peculiarity of this modification is the fixation of the drive loop behind the esophagus in the posterior mediastinum, the imposition of temporary esophageal-diaphragmatic sutures on the anterior wall of the esophagus; formation of an antireflux anastomosis due to its intussusception by these sutures into the outlet loop of the small intestine. The advantages of this modi- 
fication are: the simplicity of the proposed operation, reducing the intervention time to a minimum, which allows you to use it also to perform gastrectomy at the height of bleeding with good results [6].

With cardiac cancer, proximal or total gastrectomy should be used. We share the opinion of S.A. Geshelina (1988) [1], who agrees with other authoritative specialists that in urgent operations to perform a total gastrectomy, compared with proximal, more justified, technically simpler, more reliable and more radical, is accompanied by fewer postoperative complications and lower mortality. In cases of gastric cancer, a significant part of the small curvature and distal parts of the stomach, in tumors with differentiation G3 and G4, in tumors type 3 and 4 according to Bormann, performed a total gastrectomy with lymphadenectomy. Tumors with high differentiation G1 and G2, and tumors 1 and 2 types according to Bormann need to perform a distal gastrectomy with lymphadenectomy. However, in cases weak condition of the patient, a common tumor process, palliative resections, including atypical ones, can be used. At the recovery stage, we prefer modifications of resection by BillrothII on a long loop with an intestinal anastomosis.

\section{Conclusions}

1. In patients with gastric cancer complicated by perforation, in a serious condition of the patient and the presence of diffuse peritonitis, we consider it appropriate to use two-stage surgical tactics.

2 . The introduction of the proposed surgical tactics and new surgical interventions contributed to an increase in the number of radical operations from $4(21.0 \%)$ - in the comparison group to $6(31.6 \%)-$ in the main group and reduced postoperative mortality from $15.8 \%$ (3 patients) up to $10.5 \%$ (2 patients), respectively.

\section{ПЕРЕЛІК ПОСИЛАНЬ}

1. Гешелін С А. Невідкладна онкохірургія. Здоров’я. $1988 ; 1: 200$

2. Давидов М І. Онкологія. Клінічні рекомендації. 2015;1; 680.

3. Кіркілевський С I, Дубініна В Г, Лукьянчук О В., Машуков, Лурін А Г, Біленко О А, та ін. Клінічна хірургія. 2017;12: 20-23. Режим доступу: http://nbuv.gov. ua/UJRN/K1Kh_2017_12_7
4. Шалімов О О, Саенко В Ф. Хірургія травного тракту Здоров'я. 1987;1:563.

5. Mahar AL, Brar SS, Coburn NG, Law C, Helyer LK. Surgical management of gastric perforation in the setting of gastric cancer. Gastric Cancer. 2012 Sep;15 Suppl 1:S14652. PubMed PMID: 21983994.

6. Патент України № 11127 від 06.05.1999 р. Спосіб гастректомії В Т. Зайцев, В В Бойко, В П Далавурак, М П Донець, I А Тарабан.

\section{REFERENCES}

1. Heshelin S A. Urgent oncosurgery. Zdorov'ia. 1988;1:200. (In Russ.)

2. Davydov M I. Oncology. Clinical guidelines. Publishing group of GA N.N. Blokhin National Medical Research Center of Oncology. 2015;1; 680. (In Russ.)

3. Kirkilevskyi C I, Dubinina V H, Lukianchuk O V, Mashukov, Lurin A H, Bilenko O A, et al. Clinical surgery. 2017;12: 20-23. (In Russ.) http://nbuv.gov.ua/UJRN/ KIKh_2017_12_7
4. Shalimov O O , Saenko V F. Surgery of digestive tract. Zdorov'ia. 1987;1:563. (In Russ.)

5. Mahar AL, Brar SS, Coburn NG, Law C, Helyer LK. Surgical management of gastric perforation in the setting of gastric cancer. Gastric Cancer. 2012 Sep;15 Suppl 1:S14652. PubMed PMID: 21983994.

6. Patent of Ukraina № 11127 vid 06.05 .1999 r. The way of gastrectomy VT Zaitsev, VV Boiko, VP Dalavurak, MP Donets, IA Taraban. (In Ukr.) 
ЛІКУВАННЯ ХВОРИХ

НА РАК ШЛУНКУ, ЩО УСКЛАДНЕНИЙ ПЕРФОРАЦІЄЮ.

\section{В. В. Бойко, \\ I. В. Криворотько, \\ В. О. Лазирський}

Реферат. Bcтуn. Незважаючи на тенденцію зниження захворюваності на рак шлунку проблема лікування ускладнених форм захворювання залишається однією 3 найбільш актуальних.

Мета дослідження - покращення результатів лікування хворих на ускладнений рак шлунку.

Матеріали та методи. Дослідження засноване на аналізі результатів лікування 19 хворих на рак шлунку, що ускладнений перфорацією, які перебували на лікуванні у «ДУ Інститут загальної та невідкладної хірургії ім. В. Т. Зайцева НАМН України» 32011 по 2020 р. у віці від 18 до 85. Всі хворі поділені на дві групи: порівняння - 9(47,3 \%) хворих (перебували на лікуванні з 2011 по 2015 р.), основну - 10(52,7 \%) хворих (період лікування з 2016 по 2020 р.).

Результати та обговорення. У групі порівняння застосовувалися загальноприйняті хірургічна тактика і операції. В основній групі використовувалася активно-індивідуалізована двоетапна хірургічна тактика, що припускає ушивання перфоративного отвору на першому етапі та комбіновані й реконструктивновідновлювальні операції на другому. Радикальні операції виконано у 10 (52,6 \%) хворих; у 9 (47,4 \%) - паліативні та симптоматичні. Післяопераційні ускладнення виникли у 5 хворих (26,3 \%), післяопераційна летальність склала 26,3 \% (5 хворих).

Висновки. У хворих на рак шлунку, що ускладнений перфорацією, при тяжкому стані пацієнта і наявності розлитого перитоніту вважаємо за доцільне застосування двоетапної хірургічної тактики. Впровадження запропонованої хірургічної тактики й нових оперативних утручань сприяло збільшенню числа радикальних операцій з 4 (21,0\%) в групі порівняння до $6(31,6 \%)$ в основній групі і зниженню післяопераційної летальності з 15,8 до 10,5 \% відповідно.

Ключові слова: рак шлунку, перфорація, хірургічне лікування.

Реферат. Введение. Несмотря на тенденцию снижения заболеваемости раком желудка проблема лечения осложненных форм заболевания остается одной из наиболее сложных и актуальных.

Цель. Улучшение результатов лечения больных раком желудка, осложненным перфорацией.

Материалы и методы. Приведен анализ результатов оперативного лечения 19 больных раком желудка, осложненным перфорацией, которые находились на лечении в ГУ «ИОНХ им. В. Т. Зайцева НАМН Украины» с 2011 по 2020 г. Все больные разделены на две группы.

Результаты и обсуждение. В группе сравнения применялась общепринятая хирургическая тактика и операции. В основной группе применялась активно-индивидуализированная хирургическая тактика. Радикальные операции выполнены у $10(52,6 \%)$ больных; у 9 (47,4 \%) - паллиативные и симптоматические. Послеоперационные осложнения возникли у 5 больных $(26,3 \%)$, послеоперационная летальность составила 26,3 \% (5 больных).

Выводы. У больных раком желудка, осложненным перфорацией, при тяжелом состоянии пациента и наличии разлитого перитонита целесообразно применение двухэтапной хирургической тактики. Данная тактика способствовала увеличению числа радикальных операций с $4(21,0 \%)$ в группе сравнения до $6(31,6 \%)$ в основной группе и снижению послеоперационной летальности с 15,8 до $10,5 \%$ соответственно.

Ключевые слова: рак желудка, перфорация, хирургическое лечение. 